Original Article

\title{
Genetic diversity and molecular characterization of Cucumber mosaic cucumovirus (CMV) subgroup II infecting Spinach (Spinacia oleracea) and Pea (Pisum sativum) in Pothwar region of Pakistan
}

\author{
Diversidade genética e caracterização molecular do Cucumber mosaic cucumovirus \\ (CMV) subgrupo II infectando espinafre (Spinacia oleracea) e ervilha (Pisum sativum) \\ na região de Pothwar, Paquistão
}

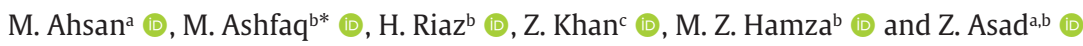 \\ apMAS-Arid Agriculture University, Department of Plant Pathology, Rawalpindi, Pakistan \\ ${ }^{b}$ MNS-University of Agriculture, Institute of Plant Protection, Plant Pathology, Multan, Pakistan \\ 'MNS-University of Agriculture, Institute of Plant Breeding and Biotechnology, Multan, Pakistan
}

\begin{abstract}
Cucumber mosaic virus (CMV) is a tremendous threat to vegetables across the globe, including in Pakistan. The present work was conducted to investigate the genetic variability of CMV isolates infecting pea and spinach vegetables in the Pothwar region of Pakistan. Serological-based surveys during 2016-2017 revealed 31.70\% overall CMV disease incidence from pea and spinach crops. Triple-antibody sandwich enzyme-linked immunosorbent assay (TAS-ELISA) revealed that all the positive isolates belong to CMV subgroup II. Two selected cDNA from ELISA-positive samples representing each pea and spinach crops were PCR-amplified ( $c a .1100 \mathrm{bp}$ ) and sequenced corresponding to the CMV CP gene which shared 93.7\% nucleotide identity with each other. Both the sequences of CMV pea (AAHAP) and spinach (AARS) isolates from Pakistan were submitted to GenBank as accession nos. MH119071 and MH119073, respectively. BLAST analysis revealed 93.4\% sequence identity of AAHAP isolate with SpK (KC763473) from Iran while AARS isolate shared maximum identity (94.5\%) with the strain 241 (AJ585519) from Australia and clustered with some reference isolates of CMV subgroup II from UK (Z12818) and USA (AF127976) in a Neighbourjoining phylogenetic reconstruction. A total of 59 polymorphic (segregating) sites (S) with nucleotide diversity $(\pi)$ of 0.06218 was evident while no INDEL event was observed in Pakistani isolates. The evolutionary distance of Pakistani CMV isolates was recorded as 0.0657 with each other and 0.0574-0.2964 with other CMV isolates reported elsewhere in the world. A frequent gene flow ( Fst $=0.30478<0.33$ ) was observed between Pakistani and earlier reported CMV isolates. In genetic differentiation analysis, the value of three permutation-based statistical tests viz; Z (84.3011), Snn (0.82456), and Ks* (4.04042) were non-significant. The statistical analysis revealed the values $2.02535,0.01468$, and 0.71862 of Tajima's D, Fu, \& Li's F* and D* respectively, demonstrating that the CMV population is under balancing selection.
\end{abstract}

Keywords: RNA virus, Cucumber mosaic virus, coat protein, pea, spinach.

\begin{abstract}
Resumo
Cucumber mosaic cucumovirus (CMV) é uma tremenda ameaça aos vegetais em todo o mundo, inclusive no Paquistão. O presente trabalho foi conduzido para investigar a variabilidade genética de isolados de CMV infectando vegetais de ervilha e espinafre na região de Pothwar, Paquistão. Pesquisas com base em sorologia durante 2016-2017 revelaram 31,70\% da incidência geral da doença por CMV em safras de ervilha e espinafre. O ensaio de imunoabsorção enzimática em sanduíche de anticorpo triplo (TAS-ELISA) revelou que todos os isolados positivos pertencem ao subgrupo II do CMV. Dois cDNA selecionados de amostras positivas para ELISA representando cada safra de ervilha e espinafre foram amplificados por PCR ( $c a .1100 \mathrm{pb}$ ) e sequenciados correspondendo ao gene CMV CP que compartilhou 93,7\% de identidade de nucleotídeo um com o outro. Ambas as sequências de isolados de ervilha CMV (AAHAP) e espinafre (AARS) do Paquistão foram submetidas ao GenBank como nos de acesso. MH119071 e MH119073, respectivamente. A análise BLAST revelou 93,4\% de identidade de sequência do isolado AAHAP com SpK (KC763473) do Irã, enquanto o isolado AARS compartilhou a identidade máxima (94,5\%) com a cepa 241 (AJ585519) da Austrália e agrupada com alguns isolados de referência do subgrupo II de CMV do Reino Unido (Z12818) e EUA (AF127976) em uma reconstrução filogenética vizinha. Um total de 59 sítios polimórficos (segregantes) (S)
\end{abstract}

*e-mail: mashfaq1642@gmail.com; mashfaq@mnsuam.edu.pk

Received: November 25, 2020 - Accepted: April 13, 2021

This is an Open Access article distributed under the terms of the Creative Commons Attribution License, which permits unrestricted use, distribution, and reproduction in any medium, provided the original work is properly cited. 
com diversidade de nucleotídeos $(\pi)$ de 0,06218 foi evidente, enquanto nenhum evento INDEL foi observado em isolados do Paquistão. A distância evolutiva de isolados de CMV do Paquistão foi registrada como 0,0657 entre si e 0,0574-0,2964 com outros isolados de CMV relatados em outras partes do mundo. Um fluxo gênico frequente (Fst $=0,30478<0,33$ ) foi observado entre os isolados de CMV do Paquistão e relatados anteriormente. Na análise de diferenciação genética, os valores de três testes estatísticos baseados em permutação viz, Z (84,3011), Snn $(0,82456)$ e Ks * $(4,04042)$ não foram significativos. A análise estatística revelou os valores 2,02535, 0,01468 e 0,71862 de Tajima's D, Fu, \& Li's F* e D* respectivamente, demonstrando que a população de CMV está sob seleção de balanceamento.

Palavras-chave: vírus do RNA, vírus do mosaico do pepino, proteína da capa, ervilha, espinafre.

\section{Introduction}

The Pothwar region, (longitude $71^{\circ} 10-73^{\circ} 55 \mathrm{E}$; latitude $32^{\circ} 10-34^{\circ} 9 \mathrm{~N}$ ), covering $22,254 \mathrm{Km}^{2}$ area of northern Punjab province lies in the north-eastern part of Pakistan with diverse vegetation comprising fruits, ornamentals, vegetables as well as cereal crops, and small forests (Ashfaq et al., 2017; Riaz et al., 2022). Attock, Rawalpindi, Chakwal and Jehlum districts and capital territory Islamabad constitute this diversified region (Cheema et al., 2013). Spinach (Spinacia oleracea) and Pea (Pisum sativum) are among the most important rabbi vegetables which covers 0.035 million hectares $(\mathrm{MH})$ with an average production of 1.57 MT (Pakistan, 2018). The average yield per acre of these vegetables in Pakistan is quite low due to several biotic and abiotic factors. Plant viruses, notably Cucumber mosaic virus (CMV) is known to cause devastating losses and reduce crop quality and quantity and a serious threat to hamper the regional vegetable production (Rehman et al., 2015).

CMV is a type member of the Cucumovirus genus having a tripartite genome with three genomic RNAs, each of which is separately enclosed in an isometric particle of $28 \mathrm{~nm}$ diameter (Azizi and Shams-Bakhsh, 2014). Single-stranded RNA (RNA1, 2, and 3) has positive sense segments of size $3.4 \mathrm{~kb}, 3.0 \mathrm{~kb}$, and $2.2 \mathrm{~kb}$ with five open reading frames (ORFs) (Mochizuki and Ohki, 2012). The genes perform multiple functions where host specificity, symptoms induction, long-distance movement, interviral recombination and virulence determination are controlled by ORF $1,2 a$ and $2 b$ located on RNA1 and RNA2 while RNA 3 encodes for capsid protein (CP; translated from subgenomic RNA 4) and movement protein (MP) responsible for movement of virions from cell to cell, involved in the transmission of CMV from infected to healthy plants through aphids (Shi et al., 2008; Nouri et al., 2014; Ohshima et al., 2016).

The insect vectors transmit the plant viruses in either persistent, semi-persistent or non-persistent manners (Dietzgen et al., 2016). Most of the plant viruses are transmitted by aphids and, more than 70 aphid species are involved in non-persistent transmission of CMV (Iqbal et al., 2011). The host range of CMV is about 101 plant families with more than 1000 plant species covering cucurbits, fruits, ornamentals, solanaceous, and vegetable crops (Edwardson and Christie, 1991). The CMV strains are demarcated into two groups viz. subgroup I and II based on the serological and genome sequence while phylogeny further divided the subgroup I into further two groups (Jacquemond, 2012).
CMV holds a significant position among plant viruses infecting various crops in Pakistan and causes massive vegetable loss (Ashfaq et al., 2014; Mozamil et al., 2019). Although it has been reported that CMV infects a limited vegetable species viz., chilli, tomato, melon and pea in Pakistan (Mughal, 1985; Akhtar et al., 2008; Malik et al., 2010; Iqbal et al., 2012; Ahsan and Ashfaq, 2018). However, there is a need to explore other important vegetables and areas systematically for the infection of CMV. Moreover, data regarding the prevalence of different strains and genetic diversity of CMV infecting major vegetables are quite less. Considering these points present study was conducted for identification and characterization of CMV infecting spinach and peas grown in Pothwar region of Pakistan.

\section{Materials and Methods}

\subsection{Field surveys and serodiagnosis of CMV in Pothwar region}

Cucumber mosaic virus disease (CMVD) surveys were carried out in Pothwar region (Attock, Chakwal, Jhelum, Rawalpindi and the capital territory of Islamabad) (Figure 1) during 2016-2017 by following random stratified design (Khan et al., 2015). In 2016 and 2017, 172 and 175, respectively, pea and spinach leaf samples displaying suspected CMVD symptoms such as mosaic, interveinal chlorosis, chlorotic streaks, unusually thick lateral veins with malformed shoestring leaves, and misshapen fruits were collected, put on ice in an ice-bucket and brought to the Plant Virology Lab, Department of Plant Pathology, PMAS Arid Agriculture University Rawalpindi, Pakistan. All the samples were subjected to serological assay and positive samples were stored at $-20^{\circ} \mathrm{C}$ for identification and characterization of the viral agents.

The preliminary CMV detection was conducted by DAS-ELISA kit (Cat. No. SRA 44501/0500, Agdia Inc., USA), with positive and negative controls, as per manufacturer instructions and methodology employed by Clark and Adams (1977). The absorbance values (405 nm) were measured with an Automatic ELISA Reader (HER-480 HT Company (Illford) Ltd., UK). Samples were considered positive for CMV infection when the ELISA absorbance value was equal to two times or higher than the average of absorbance value of the healthy tissue as well as negative control (Ashfaq et al., 2014). Commercial positive and negative controls (Agdia) were included in CMV ELISA kit. The relative disease incidence was determined with ELISA 


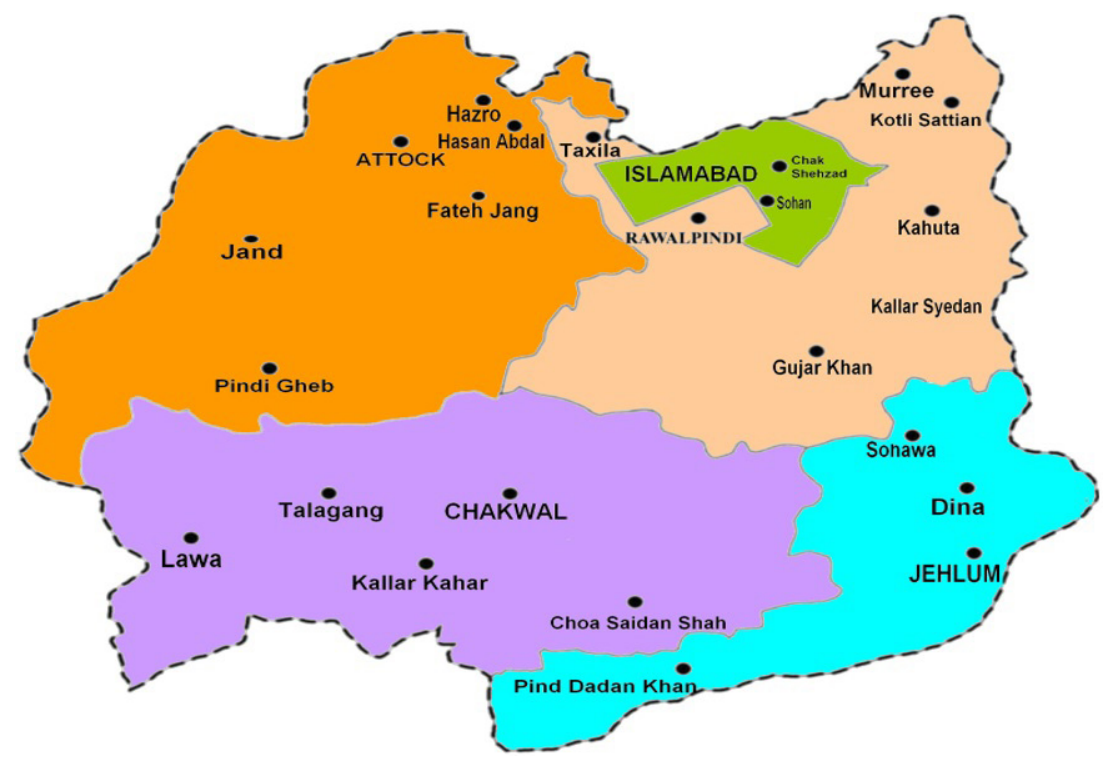

Figure 1. Map of Pothwar region of Pakistan.

positive samples by applying the following proportionate test (Steel and Torrie, 1980) (Equation 1).

$$
\% \text { D. I. of CMV }=\frac{\text { No. of ELISA }+ \text { ive samples }}{\text { Total no. of tested Samples }} \times 100
$$

\subsection{Serotyping of CMV isolates using monoclonal antibodies}

Plant sap from DAS-ELISA positive samples were extracted and used to identify serogroups in Triple Antibody Sandwich (TAS) ELISA. For this purpose, commercially available TAS-ELISA kits (Cat No. PSA 44700/0480 and SRA 44800/0500, Agdia Inc., USA) containing positive and negative controls and poly/monoclonal antibodies were used. TAS-ELISA was performed as prescribed by vendor and others (Hosseinzadeh et al., 2012).

\subsection{Total RNA extraction and RT-PCR}

The TRIzol $®$ Reagent (Life Technologies, USA) was used for total RNA isolation from serologically positive samples and subsequently checked for quantity and quality by Nanodrop (Thermo Fisher Scientific Co. USA) followed by Complementary DNA (cDNA) synthesis (Ahsan et al., 2020, Riaz et al., 2022).

The whole mixture was subjected to incubation at two different temperatures $\left(42{ }^{\circ} \mathrm{C}\right.$ and $70^{\circ} \mathrm{C}$ ) with an incubation period of $60 \mathrm{~min}$ and $10 \mathrm{~min}$ respectively. For PCR amplification, a standard PCR reaction was performed according to the Chen (2003), The primer pair CMVF-45 (5'-CCC CGG ATC CAC ATC AYA GTT TTR AGR TTC AAT TC-3') and CMVR-45 (5'-CCC CGG ATC CTG GTC TCC TT -3') was used, which amplifies a fragment of approximately 1100bp consisting of a 5' NTR and a complete CP gene. The pre-stained agarose gel $(1.0 \% \mathrm{w} / \mathrm{v})$ was used to separate amplified products and visualized under UV transilluminator (Vilber Lourmat, Serial number 6532).

\subsection{Cloning and sequencing}

The PCR amplicons were ligated to the pTZ57R/T vector (InsTAclone ${ }^{\mathrm{TM}}$ PCR cloning kit, Thermoscientific, USA; Cat No. K1214) after purification with GeneJET PCR Purification Kit, Thermoscientific, USA; Cat No. K0702). The heat shock method was employed to transform recombinant plasmids into chemically synthesized XL1-Blue strain of E. coli competent cells (Chan et al., 2013) for $50 \mathrm{sec}$ at $42^{\circ} \mathrm{C}$. The recombinant plasmid, from transformed cells, was extracted using GeneJET Plasmid Miniprep Kit (Thermoscientific, USA) by procedure followed by Ahsan et al. (2020). The recombinant plasmid was confirmed by EcoRI and HindIII restriction digestion analysis and sequenced in both orientations (Macrogen, South Korea).

The sequence homology was checked by NCBI BLASTn tool (Zhang et al., 2000) with reported CMV isolates/ strains associated with subgroup I (A\&B) and II (Table 1) and pairwise sequence comparisons along with nucleotide/ amino acid identities of selected sequences were calculated by CLUSTAL W embedded in BioEdit v7.2.6.1 (Thompson et al., 1994; Kumar et al., 2016). The phylogeny was constructed by Neighbour-joining method with 1000 bootstrap value in MEGA 6 software (Tamura et al., 2013).

\subsection{Recombination and selection pressure analysis}

The Nucleotide diversity ( $\pi$ ), number of polymorphic (segregation site, S), insertion and deletions (INDEL's), haplotype diversity (Hd) and synonymous (Ka) and non-synonymous (Ks) rate of mutations, gene flow, genetic differentiation and neutrality within each group and defined region, statistical tests like Fst, Z, Ks*, Snn, Tajima's D, Fu, Li's D* and F* were calculated using DnaSP v 6.12.03 (Tajima, 1989; Fu and Li, 1993; Li and Fu, 1994; Rozas et al., 2017 ). Recombination events were observed in aligned BrYV sequences with all the standard methods using the default settings implemented in RDP4 package (Martin et al., 2017). Recombination breakpoints are deemed important if four or more methods were assisted. 


\section{Results}

\subsection{Survey and the incidence of CMV}

Survey results revealed that CMV is well established in Pothwar region as it was found infecting both the understudied vegetables, i.e. spinach and pea with an overall $31.70 \%$ disease incidence during 2016-17. During 2016-17, of 172 pea leaf samples, only 69 samples were reacted positively to CMV-specific DAS ELISA with an average incidence of $40.12 \%$. In 2016, of 89 pea leaf samples only 34 (38.20\%) were ELISA positive with the highest disease incidence of CMV in Rawalpindi (50\%) followed by Attock (47.62\%) Islamabad (40\%), Chakwal (30\%) and Jhelum district (18.75\%). In 2017, out of 83 pea samples only 35 (42.17\%) showed positive reaction to CMV with maximum disease incidence in Rawalpindi (54.55\%) followed by Attock (50\%), Islamabad (41.67\%) and Chakwal (33.33\%), and Jhelum district (21.43\%) (Table 2). In case of spinach crop, 175 leaf samples were screened during 2016-17, of which 41 (23.43\%) samples were positive to the CMV specific DAS-ELISA. In 2016, Attock topped with the highest disease incidence (38.1\%) followed by Chakwal (20\%), Rawalpindi (16.67\%), and Islamabad (11.11\%), while the lowest was in Jhelum (6.67\%). In 2017, the highest disease incidence was documented in Attock (30.43\%) followed by Islamabad (27.27\%), Rawalpindi (26.09\%), Jhelum (23.08\%) and Chakwal (22.73\%). Serotyping studies revealed that all the positive isolates belong to CMV subgroup II.

\subsection{RT-PCR and sequence analysis}

The CMVF-45/CMVR-45 (Chen, 2003) primer pair amplified the expected $1100 \mathrm{bp}$ DNA fragments for ELISA positive samples (Figure 2). Sequences confirmed that CMV was present in DAS-ELISA positive samples. Both

Table 1. Nucleotide Identity \%ages and Ka/Ks ratio of CP gene of Pakistani CMV isolates with others.

\begin{tabular}{|c|c|c|c|c|c|c|c|c|c|}
\hline \multirow{2}{*}{ Country } & \multirow{2}{*}{ Strain } & \multirow{2}{*}{ Subgroup } & \multirow{2}{*}{$\begin{array}{l}\text { Accession } \\
\text { No }\end{array}$} & \multirow{2}{*}{ Ka } & \multirow{2}{*}{ Ks } & \multirow{2}{*}{$\mathrm{Ka} / \mathrm{Ks}$} & \multicolumn{2}{|c|}{$\begin{array}{l}\text { NT identity \% of } \\
\text { Pakistani isolates }\end{array}$} & \multirow{2}{*}{ Reference } \\
\hline & & & & & & & $\begin{array}{l}\text { MH119071 } \\
\text { (AAHAP) }\end{array}$ & $\begin{array}{l}\text { MH119073 } \\
\text { (AARS) }\end{array}$ & \\
\hline Pakistan & AARP & II & MF100856 & 0.0021 & 0.3102 & 0.0068 & 93.4 & 94.2 & $\begin{array}{c}\text { Ahsan and } \\
\text { Ashfaq (2018) }\end{array}$ \\
\hline Australia & 241 & II & AJ585519 & 0.0021 & 0.2741 & 0.0077 & 94.0 & 94.5 & Unpublished \\
\hline Iran & SpK & II & КC763473 & 0.0000 & 0.2659 & 0.0000 & 94.3 & 94.2 & Unpublished \\
\hline China & SC-J1 & II & KT932936 & 0.0125 & 0.3368 & 0.0371 & 92.2 & 93.4 & Unpublished \\
\hline USA & LS & II & AF127976 & 0.0021 & 0.2829 & 0.0074 & 93.9 & 94.3 & $\begin{array}{c}\text { Roossinck et al. } \\
\text { (1999) }\end{array}$ \\
\hline Australia & Q & II & M21464 & 0.0021 & 0.2917 & 0.0072 & 93.7 & 94.2 & $\begin{array}{c}\text { Davies and } \\
\text { Symons (1988) }\end{array}$ \\
\hline UK & Kin & II & Z12818 & 0.0021 & 0.2659 & 0.0079 & 94.2 & 94.2 & $\begin{array}{c}\text { Boccard and } \\
\text { Baulcombe } \\
\text { (1993) }\end{array}$ \\
\hline Hungary & Trk7 & II & L15336 & 0.0114 & 0.2885 & 0.0395 & 93.1 & 78.7 & $\begin{array}{l}\text { Salánki et al. } \\
\text { (1994) }\end{array}$ \\
\hline Japan & CS & IA & D28489 & 0.1201 & 0.996 & 0.1206 & 76.6 & 78.6 & $\begin{array}{c}\text { Chaumpluk et al. } \\
\text { (1996) }\end{array}$ \\
\hline Japan & Leg & IA & D16405 & 0.1189 & 1.0817 & 0.1099 & 76.2 & 78.7 & $\begin{array}{c}\text { Karasawa et al. } \\
\text { (1997) }\end{array}$ \\
\hline Taiwan & NT9 & IA & D28780 & 0.1249 & 0.9798 & 0.1275 & 76.5 & 93.3 & $\begin{array}{l}\text { Hsu et al. } \\
\text { (1995) }\end{array}$ \\
\hline USA & M & IA & D10539 & 0.1324 & 1.1142 & 0.1188 & 75.1 & 76.9 & $\begin{array}{l}\text { Owen et al. } \\
\text { (1990) }\end{array}$ \\
\hline USA & Sny & IA & U66094 & 0.1228 & 1.1041 & 0.1112 & 75.7 & 78.0 & $\begin{array}{c}\text { Gal-On et al. } \\
\text { (1996) }\end{array}$ \\
\hline USA & Fny & IA & D10538 & 0.1203 & 1.1066 & 0.1087 & 75.9 & 78.1 & $\begin{array}{l}\text { Owen et al. } \\
\text { (1990) }\end{array}$ \\
\hline India & PhyM & IB & X89652 & 0.1187 & 1.0007 & 0.1186 & 76.6 & 78.4 & $\begin{array}{l}\text { Haq et al. } \\
\text { (1996) }\end{array}$ \\
\hline Malaysia & CLW2 & IB & JN054635 & 0.1212 & 0.9568 & 0.1267 & 76.8 & 78.3 & Unpublished \\
\hline India & $\begin{array}{l}\text { KKG- } \\
\text { MP }\end{array}$ & IB & HQ343232 & 0.1235 & 1.1042 & 0.1118 & 75.7 & 77.8 & Unpublished \\
\hline
\end{tabular}


the sequences of CMV pea (AAHAP) and spinach (AARS) isolates from Pakistani were submitted to GenBank as accession nos. MH119071 and MH119073, respectively. For each CMV isolate, the sequence contains a complete $\mathrm{CP}$ gene of $657 \mathrm{bp}$ along with some portion of 5 ' and 3' UTR. Sequence identity matrix revealed that both isolates belong to subgroup II isolates with $93.7 \%$ similarity with each other and 92.2-94.5\% with CMV subgroup II isolates reported elsewhere in the world. Isolate AAHAP shared highest nucleotide identity (93.4\%) with the isolate SpK (KC763473) from Iran, while Pakistani isolate AARS shared maximum identity (94.5\%) with the strain 241 (AJ585519) from Australia.

Phylogenetic analysis revealed that all the isolates were grouped into three well-separated clusters in accordance with the sequences of the close relatives in the same subgroups (IA, IB and II) (Figure 3). The two new AAHAP

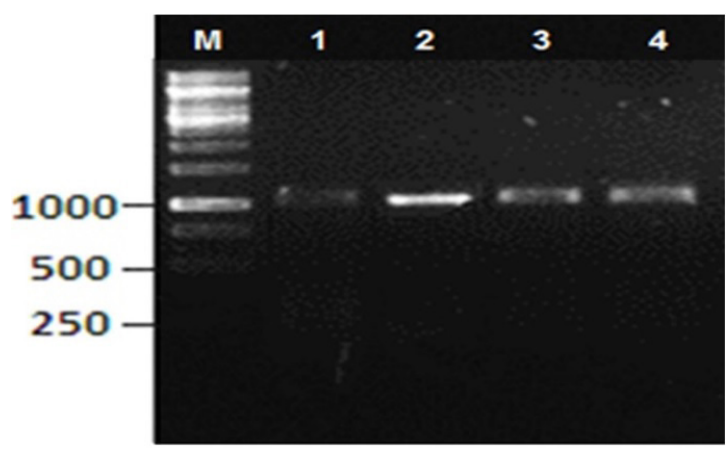

Figure 2. Amplification of CMV using specific primers. Expected band of 1100 bp was obtained on agarose gel (1\%). M is $1 \mathrm{~kb}$ ladder. Lane 1, 2, 3 and 4 are showing ca.1100 bp band of CMV samples. and AARS isolates form distant clads with some proven standard subgroup II isolates i.e. SC-J1 from China, Kin from UK, Q and strain 241 from Australia, Trk7 from Hungary, isolate SpK from Iran, and LS from USA which are consistent with previous studies (Chaumpluk et al., 1996; Gal-On et al., 1996; Haq et al., 1996; Boccard and Baulcombe, 1993; Roossinck et al., 1999; Takanami et al., 1999). Phylogeny results indicate that in Pothwar region of Pakistan pea and spinach are solely infected by CMV subgroup II rather than subgroup I.

\subsection{Selection pressure and recombination analysis}

Sequence polymorphisms were observed in 660bp of sequence within $19 \mathrm{CMV}$ isolates, covering complete $\mathrm{CP}$ cistron. A total of 217 polymorphic (segregating) sites (S) were observed, out of which 41 were singleton variable and 175 parsimony informative sites with Eta of 264. Overall Nucleotide diversity $(\pi)$ in all the understudied 19 isolates was 0.14073 while a total of 6 INDEL events were observed which were present in other than Pakistani isolates. Haplotype diversity analysis revealed that there were a total 19 haplotypes with haplotype diversity (Hd) of 1.00 in all the 19 isolates. Nucleotide diversity analysis among the populations revealed the presence of $59 \mathrm{~S}$ sites with $\pi$ of 0.06218 in Pakistani isolates while 208 (S) and $0.014063(\pi)$ was in the isolates reported from other parts of the world. The average number of nucleotide differences (k) i.e. 40.667 and 92.035 were observed in isolates reported from Pakistan and other parts of the world, respectively.

The evolutionary distance of Pakistani CMV isolates was recorded as 0.0657 with each other and 0.0574-0.2964 with isolates from other countries. AAHAP isolate had the lowest evolutionary distance of 0.0589 from Iranian SpK isolate while the AARS had 0.0574 from Australian

Table 2. Disease incidence \%age of CMV infecting vegetables in Pothwar.

\begin{tabular}{|c|c|c|c|c|c|c|c|}
\hline \multirow[b]{2}{*}{ Crop } & \multirow[b]{2}{*}{ District } & \multicolumn{3}{|c|}{2016} & \multicolumn{3}{|c|}{2017} \\
\hline & & Total Tested & $\begin{array}{l}\text { Infected } \\
\text { Samples }\end{array}$ & D. I. \% & Total Tested & $\begin{array}{l}\text { Infected } \\
\text { Samples }\end{array}$ & ${ }^{*}$ D. I. \% \\
\hline \multirow[t]{6}{*}{ Pea } & Attock & 21 & 10 & 47.62 & 20 & 10 & 50.00 \\
\hline & Chakwal & 20 & 6 & 30.00 & 15 & 5 & 33.33 \\
\hline & Jehlum & 16 & 3 & 18.75 & 14 & 3 & 21.43 \\
\hline & Rawalpindi & 22 & 11 & 50.00 & 22 & 12 & 54.55 \\
\hline & Islamabad & 10 & 4 & 40.00 & 12 & 5 & 41.67 \\
\hline & Sub Total (A) & 89 & 34 & 38.20 & 83 & 35 & 42.17 \\
\hline \multirow[t]{7}{*}{ Spinach } & Attock & 21 & 8 & 38.10 & 23 & 7 & 30.43 \\
\hline & Chakwal & 20 & 4 & 20.00 & 22 & 5 & 22.73 \\
\hline & Jehlum & 15 & 1 & 6.67 & 13 & 3 & 23.08 \\
\hline & Rawalpindi & 18 & 3 & 16.67 & 23 & 6 & 26.09 \\
\hline & Islamabad & 9 & 1 & 11.11 & 11 & 3 & 27.27 \\
\hline & Sub Total (B) & 83 & 17 & 20.48 & 92 & 24 & 26.09 \\
\hline & Total $(A+B)$ & 172 & 51 & 29.65 & 175 & 59 & 33.71 \\
\hline
\end{tabular}

"Note: Disease Incidence (D. I.) is the percentage of diseased plants or parts in the sample or population of plants. 


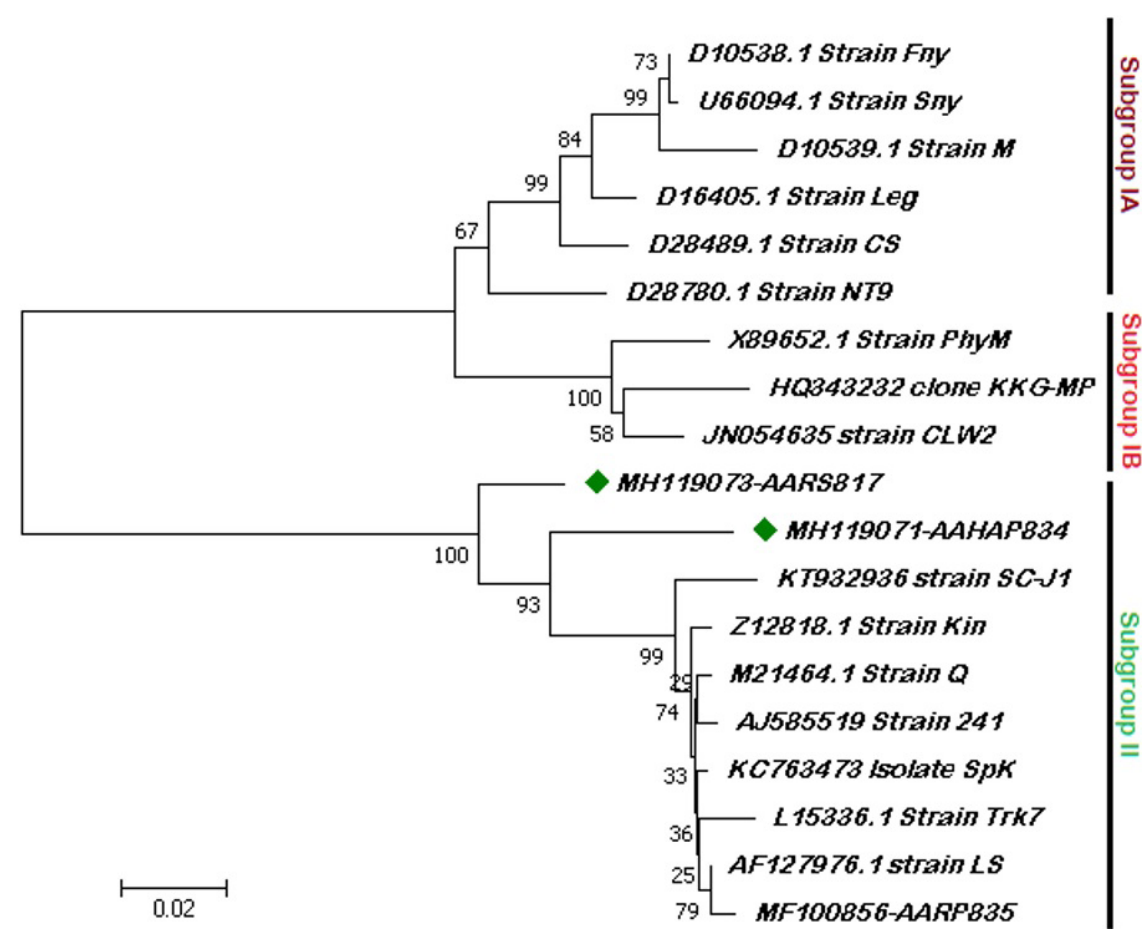

Figure 3. Evolutionary relationships of Pakistani CMV nucleotide sequences of CP gene with previously reported GenBank sequences. Phylogenetic topology shows Tamura- Nei Method of Neighbour Joining bootstrap consensus tree based on CP gene nucleotide sequences of 19 (two subgroup II) Pakistani isolates (bulleted) and related GenBank CMV sequences.

strain 241 (AJ585519). Both the isolates hold highest distance with $(0.2964 \& 0.2683)$ the subgroup IA strain M (D10539) from USA in accordance with the observations of phylogenetic analysis. The ratio of Ka to Ks was determined to test the impact of nucleotide transition on the amino acid sequence of the CMV CP gene. The Ks values were between 0.2659-1.1142 while Ka were 0.00-0.1324. Isolate D10539_USA was detected with the maximum Ka (0.1324) and Ks (1.1142) value. The ratio between Ka and Ks was estimated between 0.00 and 0.1275 . In Taiwanian NT9 isolate D28780, a comparatively high Ka / Ks value (0.1275) was reported (Table 1). No Recombination event was detected in Pakistani CMV isolates.

\subsection{Gene flow and genetic differentiation analysis}

The value of the coefficient of gene differentiation (Fst) was recorded as 0.30478 (less than 0.33 standard value) between Pakistani and other reported CMV isolates suggesting it to be a frequent gene flow. In genetic differentiation analysis, the value of three permutationbased statistical tests viz; Z (84.3011), Snn (0.82456) and $\mathrm{Ks}^{*}$ (4.04042) were found non-significant (Balasubramanian and Selvarajan, 2014). In the present study, all the values 2.02535, 0.01468 and 0.71862 of Tajima's D, Fu, \& Li's F* and $\mathrm{D}^{*}$, commonly used tests to recognize sequences that do not suit the neutral model in genetic drift and mutation equilibrium, weren't statistically significant, respectively (Tajima, 1989; Ramírez-Soriano et al., 2008) demonstrating that CMV population is under balancing selection.

\section{Discussion}

Cucumber mosaic virus is a notorious virus with a broad host range that is known to infect spinach for the first time in Pakistan. CMV has already been reported to cause losses in spinach crop grown in Brazil (Yuki et al., 2017), Greece (Fotopoulos et al., 2011), USA (Yang et al., 1997), and UK (Bailiss and Okonkwo, 1979). CMV is a pathogen widely distributed in country infecting nearly all the grown vegetables i.e. pea (Ahsan and Ashfaq, 2018), chilli (Iqbal et al., 2012), tomato (Akhtar et al., 2008) and melon (Malik et al., 2010). Extensive surveys revealed that CMV has a disease incidence of $38.2 \%$ infecting pea and $20.48 \%$ in spinach during 2016 . While in 2017 , a relatively higher incidence of CMV was observed i.e. 42.17 and 26.09 from pea and spinach, respectively. This increasing incidence of CMV during succeeding survey year was also observed by Iqbal et al. (2012), Malik et al. (2010) and Akhtar et al. (2008). Broad range of hosts, together with frequent occurrence and prevalence of CMV in the Pothwar region of Pakistan, had a significant impact on efficient vegetable production (Ashfaq et al., 2017). TASELISA revealed the presence of subgroup II in the Pothwar region as used for the serotype prevalence studies of CMV by Hosseinzadeh et al. (2012). Our findings from serotype analysis support the hypothesis presented by Hord et al. (2001) which underlines the domination of Subgroup I isolates in tropical and subtropical zones while temperate regions as Pothwar region serves home for subgroup II.

CMV is a prominent economically important bottleneck in the production of field crops, vegetables, and ornamentals 
in Pakistan (Ashfaq et al., 2017; Iqbal et al., 2012). However, less information is available on the molecular characteristics of natural populations of CMV infecting vegetables from Pakistan. The Pakistani CMV isolates were highly homologous to each other and to isolates within the same subgroup based on the $\mathrm{CP}$ gene sequence.

The already published studies indicated the higher degree of coat protein gene sequence homology of CMV isolates of the same subgroup sampled from a single crop (Ahsan and Ashfaq, 2018), as well as of its global populations (Roossinck et al., 1999; Takanami et al., 1999). The reported Pakistani isolates in this study share sufficient homology with each other and less $\pi$ value also confirms the phylogeny results as both the Pakistani isolates present in the same clad of subgroup II but despite of higher homology they cluster in distinct clads within the subgroup II clade.

Phylogenetic relationship confirms the presence of genetic variation in Pakistani isolates as they show a relationship with an isolate of different geographical location i.e. Australia, UK, USA, Japan and Hungary. Clustering of CMV isolates based on subgroups and formation of clusters with representative isolates was also reported by many scientists (Roossinck et al., 1999; Ohshima et al., 2016). Besides, mechanical means like routine handling especially at transplanting, pruning and harvesting (Dragich et al., 2014), the cucumoviruses are transmitted by infected plantlets and seeds over long distances (Yang et al., 1997; Ali and Kobayashi, 2010). Pakistan imports most of its vegetable seeds from other countries i.e. Netherland, India and China etc. and there is need to strengthen the quarantine measures in Pakistan to check the movement of seed-borne plant pathogens.

As evolutionary process, variations occur in the genetic makeup of organisms by the addition of new alleles through gene flow or mutations etc. Gene flow may be calculated with $\mathrm{Nm}$ (the number of migrants) and Fst (the degree of genetic differentiation) between sub-populations. Fst value 0.33 might be considered as a threshold level below which gene flow is frequent and above that gene flow appears infrequent (Zu et al., 2019). This study confirms the frequent gene flow with moderate population structuring as value of coefficient of gene differentiation (Fst) was recorded as 0.30478 below of standard 0.33 value. Moreover, positive values of Neutrality tests i.e. Tajima's D test, Fu, \& Li's F*, Fu, \& Li's D* indicates that CMV population is under balancing selection with an excess of high frequency variations and contraction of population (Tajima, 1989; Fu and Li, 1993; $\mathrm{Li}$ and $\mathrm{Fu}, 1994)$. Evolutionary distance describes the divergence of homologous sequences from their common ancestors (Rosenberg et al., 2005). In this study, the higher sequence identities, close phylogenetic relationship and lower evolutionary distance of Pakistani isolates from Iranian isolate justifies their geographical association but with Australian isolate also indicate the demographic expansion and these results are in agreement with Moury (2004) and Hasiów-Jaroszewska et al. (2017). The findings of the present study will enable plant breeders to develop $\mathrm{CMV}$ resilient varieties and also lead to forecast the chance of resistance breakdown in pathogen-mediated resistant transgenic lines of vegetable crops. This research is the first evidence of genetic variability of CMV in spinach from Pakistan. Moreover, continued research is needed to identify, alone or in combination with other viruses, the possible impact of this emerging class of threatening plant viruses on quality and quantity of crucifers and other vegetables.

\section{Conclusion}

CMV is a notorious pathogen, having broad host range and causes colossal losses to the vegetable crops worldwide. In the present study, CMV was detected both in spinach and pea in all sampling sites of Pothwar region with an overall disease incidence $30.71 \%$ during 2016-17. The sequences of two newly identified CMV isolates comprising a complete CP gene of 657bp along with some portion of 5' and 3'UTR. Evolutionary distance and phylogenetic analysis revealed that both the isolates have a close relationship with Iranian and Australian subgroup II isolates. Frequent gene flow with lower nucleotide diversity was detected in CMV population. Moreover, positive values of statistical tests confirm the balancing selection in understudied CMV population. Detection of CMV infection first time in spinach, relatively higher disease incidence of subgroup II isolates underlines an alarming situation for successful production of vegetable crops. Developing management techniques such as breeding projects to identify resistant sources based on genetic variation findings could help to manage this menace.

\section{Acknowledgements}

The present study was funded by Higher Education Commission of Pakistan under the Indigenous $5000 \mathrm{PhD}$ Fellowship Program.

\section{References}

AHSAN, M. and ASHFAQ, M., 2018. First report of a Cucumber mosaic virus (CMV) subgroup II isolate infecting pea in Pakistan. Journal of Plant Pathology, vol. 100, no. 3, pp. 597. http://dx.doi. org/10.1007/s42161-018-0105-z.

AHSAN, M., ASHFAQ M., MUKHTAR, T. and ABBASI, N.A., 2020. Current status and genetic variability of Cucumber mosaic cucumovirus (CMV) isolates infecting major cucurbits and solanaceous vegetables in Pothwar region of Pakistan. Pakistan Journal of Agricultural Sciences, vol. 57, no. 5, pp. 1353-1361.

AKHTAR, K.P., RYU, K.H., SALEEM, M.Y., ASGHAR, M., JAMIL, F.F., HAQ, M.A. and KHAN, I.A., 2008. Occurrence of Cucumber mosaic virus subgroup IA in tomato in Pakistan. Journal of Plant Diseases and Protection, vol. 115, no. 1, pp. 2-3. http://dx.doi. org/10.1007/BF03356231.

ALI, A. and KOBAYASHI, M., 2010. Seed transmission of Cucumber mosaic virus in pepper. Journal of Virological Methods, vol. 163, no. 2, pp. 234-237. http://dx.doi.org/10.1016/j.jviromet.2009.09.026. PMid:19819264.

ASHFAQ M., IQBAL, S., MUKHTAR, T. and SHAH, H., 2014. Screening for resistance to Cucumber mosaic cucumovirus in chilli pepper. Journal of Animal and Plant Sciences, vol. 24, pp. 791-795. 
ASHFAQ M., SALEEM, A., WAQAS, M. and MUKHTAR, T., 2017. Natural occurrence and host range studies of Cucumber mosaic virus (CMV) infecting ornamental species in Rawalpindi-Islamabad area of Pakistan. Philippine Agricultural Scientist, vol. 100, no. 1, pp. 55-61.

AZIZI, A. and SHAMS-BAKHSH, M., 2014. Impact of Cucumber mosaic virus infection on the varietal traits of common bean cultivars in Iran. Virus Disease, vol. 25, no. 4, pp. 447-454. http://dx.doi. org/10.1007/s13337-014-0233-9. PMid:25674621.

BAILISS, K. and OKONKWO, V., 1979. Virus infection of spinach (Spinacia oleracea L.) in Britain. Journal of Horticultural Science, vol. 54, no. 4, pp. 289-297. http://dx.doi.org/10.1080/002215 89.1979.11514884.

BALASUBRAMANIAN, V. and SELVARAJAN, R., 2014. Genetic diversity and recombination analysis in the coat protein gene of Banana bract mosaic virus. Virus Genes, vol. 48, no. 3, pp. 509-517. https://doi.org/10.1007/s11262-014-1056-X.

BOCCARD, F. and BAULCOMBE, D., 1993. Mutational analysis of cis-acting sequences and gene function in RNA3 of Cucumber mosaic virus. Virology, vol. 193, no. 2, pp. 563-578. http://dx.doi. org/10.1006/viro.1993.1165. PMid:8460476.

CHAN, W.T., VERMA, C.S., LANE, D.P. and GAN, S.K.E., 2013. A comparison and optimization of methods and factors affecting the transformation of Escherichia coli. Bioscience Reports, vol. 33, no. 6, pp. e00086. http://dx.doi.org/10.1042/BSR20130098. PMid:24229075.

CHAUMPLUK, P., SASAKI, Y., NAKAJIMA, N., NAGANO, H., NAKAMURA, I., SUZUKI, K., MISE, K., INOUYE, N., OKUNO, T. and FURUSAWA, I., 1996. Six new subgroup I members of Japanese cucumber mosaic virus as determined by nucleotide sequence analysis on RNA3's cDNAs. Japanese Journal of Phytopathology, vol. 62 , no. 1, pp. 40-44. http://dx.doi.org/10.3186/jjphytopath.62.40.

CHEEMA, N.M., FAROOQ U., SHABBIR, G., SHAH, M.K.N. and MUSA, M., 2013. Prospects of castor bean cultivation in rainfed tract of Pakistan. Pakistan Journal of Botany, vol. 45, no. 1, pp. 219-224.

CHEN, Y.K., 2003. Occurence of cucumber mosaic virus in ornamental plants and perspectives of transgenic control. The Netherlands: Wageningen University. PhD thesis in Virology.

CLARK, M.F. and ADAMS, A., 1977. Characteristics of the microplate method of enzyme-linked immunosorbent assay for the detection of plant viruses. The Journal of General Virology, vol. 34, no. 3, pp. 475-483. http://dx.doi.org/10.1099/0022-131734-3-475. PMid:323416.

DAVIES, C. and SYMONS, R.H., 1988. Further implications for the evolutionary relationships between tripartite plant viruses based on cucumber mosaic virus RNA 3. Virology, vol. 165, no. 1, pp. 216-224. http://dx.doi.org/10.1016/0042-6822(88)906757. PMid:3388769.

DIETZGEN, R.G., MANN, K.S. and JOHNSON, K.N., 2016. Plant virus-insect vector interactions: current and potential future research directions. Viruses, vol. 8, no. 11, pp. 303. http://dx.doi. org/10.3390/v8110303. PMid:27834855.

DRAGICH, M., MELZER, M. and NELSON, S., 2014. Cucumber mosaic virus in Hawaii. Plant Disease, vol. 101, pp. 1-10.

EDWARDSON, J. and CHRISTIE, R., 1991. Cucumoviruses. In: J. EDWARDSON and R. CHRISTIE, eds. CRC handbook of viruses infecting legumes. Boca Raton: CRC Press, pp. 293-319.

FOTOPOULOS, V., DOVAS, C.I. and KATIS, N.I., 2011. Incidence of viruses infecting spinach in Greece, highlighting the importance of weeds as reservoir hosts. Journal of Plant Pathology, vol. 93 , no. 2, pp. 389-395.
FU, Y.X. and LI, W.H., 1993. Statistical tests of neutrality of mutations. Genetics, vol.133, no. 3, pp.693-709. http://dx.doi.org/10.1093/ genetics/133.3.693. PMid:8454210.

GAL-ON, A., KAPLAN, I.B. and PALUKAITIS, P., 1996. Characterization of cucumber mosaic virus: II. Identification of movement protein sequences that influence its accumulation and systemic infection in tobacco. Virology, vol. 226, no. 2, pp. 354-361. http://dx.doi. org/10.1006/viro.1996.0663. PMid:8955055.

HAQ, Q.M.R., SINGH, B.P. and SRIVASTAVA, K.M., 1996. Biological, serological and molecular characterization of a cucumber mosaic virus isolate from India. Plant Pathology, vol. 45, no. 5, pp. 823-828. http://dx.doi.org/10.1111/j.1365-3059.1996.tb02891.x.

HASIÓW-JAROSZEWSKA, B., CHRZANOWSKI, M., BUDZYŃSKA, D., RYMELSKA, N. and BORODYNKO-FILAS, N., 2017. Genetic diversity, distant phylogenetic relationships and the occurrence of recombination events among cucumber mosaic virus isolates from zucchini in Poland. Archives of Virology, vol. 162, no. 6, pp. 1751-1756. http://dx.doi.org/10.1007/s00705-017-3285-5. PMid:28238107.

HORD, M.J., GARCÍA, A., VILLALOBOS, H., RIVERA, C., MACAYA, G. and ROOSSINCK, M., 2001. Field survey of Cucumber mosaic virus subgroups I and II in crop plants in Costa Rica. Plant Disease, vol. 85, no. 9, pp. 952-954. http://dx.doi.org/10.1094/ PDIS.2001.85.9.952. PMid:30823108.

HOSSEINZADEH, H., NASROLLANEJAD, S. and KHATERI, H., 2012. First report of cucumber mosaic virus subgroups $\mathrm{i}$ and ii on soybean, pea, and eggplant in iran. Acta Virologica, vol. 56, no. 2, pp. 145-148. http://dx.doi.org/10.4149/av_2012_02_145. PMid:22720706.

HSU, Y.H., WU, C.W., LIN, B.Y., CHEN, H.Y., LEE, M.F. and TSAI, C.H., 1995. Complete genomic RNA sequences of cucumber mosaic virus strain NT9 from Taiwan. Archives of Virology, vol. 140, no. 10, pp. 1841-1847. http://dx.doi.org/10.1007/BF01384346. PMid:7503683.

IQBAL, S., ASHFAQ M. and SHAH, H., 2011. Biological characterization of Pakistani isolates of Cucumber mosaic cucumovirus (CMV). Pakistan Journal of Botany, vol. 43, no. 6, pp. 3041-3047.

IQBAL, S., ASHFAQ, M. and SHAH, H., 2012. Prevalence and distribution of Cucumber mosaic virus (CMV) in major Chilli Growing Areas of Pakistan. Pakistan Journal of Botany, vol. 44, no. 5, pp. 1749-1754.

JACQUEMOND, M., 2012. Cucumber mosaic virus. Advances in Virus Research, vol. 84, pp. 439-504. http://dx.doi.org/10.1016/ B978-0-12-394314-9.00013-0. PMid:22682176.

KARASAWA, A., ITO, A., OKADA, I., HASE, S. and EHARA, Y., 1997. A possible role of RNA 2 of cucumber mosaic cucumovirus as a determinant of infection phenotype on cowpea. Japanese Journal of Phytopathology, vol. 63, no. 4, pp. 289-297. http:// dx.doi.org/10.3186/jjphytopath.63.289.

KHAN, M.G., REDDY, K.G. and RAO, D.K., 2015. Designing stratified sampling in economic and business surveys. Journal of Applied Statistics, vol. 42, no. 10, pp. 2080-2099. http://dx.doi.org/10.1 080/02664763.2015.1018674.

KUMAR, S., STECHER, G. and TAMURA, K., 2016. MEGA7: molecular evolutionary genetics analysis version 7.0 for bigger datasets. Molecular Biology and Evolution, vol. 33, no. 7, pp. 18701874. https://doi.org/10.1093/molbev/msw054.

LI, W.H. and FU, Y.X., 1994. Estimation of population parameters and detection of natural selection from DNA sequences. In: B. GOLDING, ed. Non-neutral evolution. Boston: Springer. http:// dx.doi.org/10.1007/978-1-4615-2383-3_10.

MALIK, A.H., MANSOOR, S., IRAM, S., BRIDDON, R.W. and ZAFAR, Y., 2010. Severe disease of melon in North West frontier province 
is associated with simultaneous infection of two RNA viruses. Pakistan Journal of Botany, vol. 42, no. 1, pp. 361-367.

MARTIN, D.P., MURRELL, B., KHOOSAL, A. and MUHIRE, B., 2017. Detecting and analyzing genetic recombination using $\mathrm{RDP}_{4}$ in bioinformatics. Methods in Molecular Biology, vol. 1525, pp. 433-460. http://dx.doi.org/10.1007/978-1-4939-6622-6_17.

MOCHIZUKI, T. and OHKI, S.T., 2012. Cucumber mosaic virus: viral genes as virulence determinants. Molecular Plant Pathology, vol. 13, no. 3, pp. 217-225. http://dx.doi.org/10.1111/j.13643703.2011.00749.x. PMid:21980997.

MOURY, B., 2004. Differential selection of genes of Cucumber mosaic virus subgroups. Molecular Biology and Evolution, vol. 21, no. 8, pp. 1602-1611. http://dx.doi.org/10.1093/molbev/ msh164. PMid:15155801.

MOZAMIL, M., KHAN, M.A., ASHFAQ M. and SHAH, M.A.S., 2019. Role of morphological traits and biochemical contents in imparting resistance against cucumber mosaic virus and zucchini yellow mosaic virus in cucumber genotypes. Philippine Agricultural Scientist, vol. 102, no. 1, pp. 75-81.

MUGHAL, S.M., 1985. Viral diseases of tomato and their control. Progressive Farming, vol. 6, no. 2, pp. 20-23.

NOURI, S., AREVALO, R., FALK, B.W. and GROVES, R.L., 2014. Genetic structure and molecular variability of Cucumber mosaic virus isolates in the United States. PLoS One, vol. 9, no. 5, pp. e96582. http://dx.doi.org/10.1371/journal.pone.0096582. PMid:24801880.

OHSHIMA, K., MATSUMOTO, K., YASAKA, R., NISHIYAMA, M., SOEJIMA, K., KORKMAZ, S., HO, S.Y., GIBBS, A.J. and TAKESHITA, M., 2016. Temporal analysis of reassortment and molecular evolution of Cucumber mosaic virus: extra clues from its segmented genome. Virology, vol. 487, pp. 188-197. http://dx.doi. org/10.1016/j.virol.2015.09.024. PMid:26539800.

OWEN, J., SHINTAKU, M., AESCHLEMAN, P., BEN TAHAR, S. and PALUKAITIS, P., 1990. Nucleotide sequence and evolutionary relationships of Cucumber mosaic virus (CMV) strains: CMV RNA 3. The Journal of General Virology, vol. 71, no. 10, pp. 2243-2249. http://dx.doi.org/10.1099/0022-1317-71-10-2243. PMid:2230731.

PAKISTAN, Ministry of National Food Security \& Research, Economic Wing, 2018. Fruit, vegetables and condiments statistics of Pakistan. Islamabad.

RAMÍREZ-SORIANO, A., RAMOS-ONSINS, S.E., ROZAS, J., CALAFELL, F. and NAVARRO, A., 2008. Statistical power analysis of neutrality tests under demographic expansions, contractions and bottlenecks with recombination. Genetics, vol. 179, no. 1 , pp. 555-567. http://dx.doi.org/10.1534/genetics.107.083006. PMid:18493071.

REHMAN, A., JINGDONG, L., SHAHZAD, B., CHANDIO, A.A., HUSSAIN, I., NABI, G. and IQBAL, M.S., 2015. Economic perspectives of major field crops of Pakistan: an empirical study. Pacific Science Review B: Humanities and Social Sciences, vol. 1, no. 3, pp. 145-158.

RIAZ, T., ASHFAQ, M. and KHAN, Z., 2022. Evaluation of the Chilli veinal mottle virus $C P$ gene expressing transgenic Nicotiana benthamiana plants for disease resistance against the virus. Brazilian Journal of Biology, vol. 82, no. 3, pp. e243692. https://doi.org/10.1590/1519-6984.243692.

ROOSSINCK, M.J., ZHANG, L. and HELLWALD, K.H., 1999. Rearrangements in the 5 ' nontranslated region and phylogenetic analyses of cucumber mosaic virus rna 3 indicate radial evolution of three subgroups. Journal of Virology, vol. 73, no. 8, pp. 6752-6758. http://dx.doi.org/10.1128/JVI.73.8.67526758.1999. PMid:10400773.
ROSENBERG, N.A., MAHAJAN, S., RAMACHANDRAN, S., ZHAO, C., PRITCHARD, J.K. and FELDMAN, M.W., 2005. Clines, clusters, and the effect of study design on the inference of human population structure. PLOS Genetics, vol. 1, no. 6, pp. e70. http:// dx.doi.org/10.1371/journal.pgen.0010070.

ROZAS, J., FERRER-MATA, A., SÁNCHEZ-DELBARRIO, J.C., GUIRAORICO, S., LIBRADO, P., RAMOS-ONSINS, S.E. and SÁNCHEZGRACIA, A., 2017. DnaSP 6: DNA sequence polymorphism analysis of large data sets. Molecular Biology and Evolution, vol. 34, no. 12, pp. 3299-3302. http://dx.doi.org/10.1093/molbev/ msx248. PMid:29029172.

SALÁNKI, K., THOLE, V., BALÁZS, E. and BURGYÁN, J., 1994. Complete nucleotide sequence of the RNA 3 from subgroup II of cucumber mosaic virus (CMV) strain: Trk7. Virus Research, vol. 31, no. 3, pp. 379-384. http://dx.doi.org/10.1016/0168-1702(94)90030-2. PMid:8191790.

SHI, B.J., SYMONS, R.H. and PALUKAITIS, P., 2008. The cucumovirus $2 \mathrm{~b}$ gene drives selection of inter-viral recombinants affecting the crossover site, the acceptor RNA and the rate of selection. Nucleic Acids Research, vol. 36, no. 4, pp. 1057-1071. http:// dx.doi.org/10.1093/nar/gkm1036. PMid:18086712.

STEEL, R.G. and TORRIE, J.H., 1980. Principles and procedures of statistics, a biometrical approach. New York: McGraw-Hill.

TAJIMA, F., 1989. Statistical method for testing the neutral mutation hypothesis by DNA polymorphism. Genetics, vol. 123, no. 3, pp. 585-595. http://dx.doi.org/10.1093/genetics/123.3.585. PMid:2513255.

TAKANAMI, Y., UCHIBA, T., SHIGEMI, T., KIKUHARA, K. and TAKESHITA, M., 1999. Specific detection of subgroups I and II of Cucumber Mosaic Virus RNA with Digoxigenin-Labeled Synthetic Oligo-Deoxyribonucleotide Probes.Japanese Journal of Phytopathology, vol. 65, no. 1, pp. 42-45. http://dx.doi. org/10.3186/jjphytopath.65.42.

TAMURA, K., STECHER, G., PETERSON, D., FILIPSKI, A. and KUMAR, S., 2013. MEGA6: Molecular Evolutionary Genetics Analysis version 6.0. Molecular Biology and Evolution, vol. 30, no. 12, pp. 2725-2729. http://dx.doi.org/10.1093/molbev/mst197. PMid:24132122.

THOMPSON, J.D., HIGGINS, D.G. and GIBSON, T.J., 1994. CLUSTAL $\mathrm{W}$ : improving the sensitivity of progressive multiple sequence alignment through sequence weighting, position-specific gap penalties and weight matrix choice. Nucleic Acids Research, vol. 22, no. 22, pp. 4673-4680. http://dx.doi.org/10.1093/ nar/22.22.4673. PMid:7984417.

YANG, Y., KIM, K.S. and ANDERSON, E.J., 1997. Seed transmission of cucumber mosaic virus in spinach. Phytopathology, vol. 87, no. 9, pp. 924-931. http://dx.doi.org/10.1094/PHYTO.1997.87.9.924. PMid:18945063.

YUKI, V., MITUTI, T., REZENDE, J.A.M., SALARORI, R., KITAJIMA, E.W. and KITAJIMA, J., 2017. First report of spinach (Spinacia oleracea) wilt caused by cucumber mosaic virus (CMV) in Brazil. Plant Disease, vol. 101, no. 12, pp. 2154. http://dx.doi.org/10.1094/ PDIS-04-17-0560-PDN.

ZHANG, Z., SCHWARTZ, S., WAGNER, L. and MILLER, W., 2000. A greedy algorithm for aligning DNA sequences. Journal of Computational Biology, vol. 7, no. 1-2, pp. 203-214. http://dx.doi. org/10.1089/10665270050081478. PMid:10890397.

ZU, H., ZHANG, H., YAO, M., ZHANG, J., DI, H., ZHANG, L., DONG, L., WANG, Z. and ZHOU, Y., 2019. Molecular characteristics of segment 5 , a unique fragment encoding two partially overlapping ORFs in the genome of rice black-streaked dwarf virus. PLoS One, vol. 14, no. 11, e0224569. http://dx.doi.org/10.1371/journal. pone.0224569. PMid:31697693. 